\title{
Lymphoma cells in cerebrospinal fluid confirmed by chromosome analysis
}

\author{
J PEARSON, EB ILGREN, * AI SPRIGGS $\dagger$ \\ From the Department of Medical Genetics, Old Road, Headington, the * Department of Neuropathology, \\ Radcliffe Infirmary, and the †Laboratory of Clinical Cytology, Churchill Hospital, Oxford
}

SUMMARY Two cases of malignant lymphoma are reported, in which lymphoma cells were undergoing cell division in the cerebrospinal fluid. In each case it was possible to perform chromosome counts and karyotype analyses, and in this way to establish that a neoplastic clone was present.

In two recent cases of lymphomatous infiltration of the meninges, it was possible to confirm the cytological diagnosis by karyotypic analysis of cells in cerebrospinal fluid (CSF).

\section{Material and methods}

Cytological examination was performed on air-dried cell preparations made with the Shandon cytocentrifuge, and stained with May-GrünwaldGiemsa.

Cytogenetic study was performed in the following way:

The suspension was divided into two equal portions. These were centrifuged at $1000 \mathrm{rpm}$ for $5 \mathrm{~min}$, the supernatants discarded, and each pellet resuspended in $5 \mathrm{ml}$ of tissue culture medium (Eagle's medium with $20 \%$ human serum). One of these cultures was incubated at $37^{\circ} \mathrm{C}$ for $24 \mathrm{~h}$ before harvesting; the other was treated as a direct preparation. Harvesting technique was the same in each case. Colcemid (0.1 $\mathrm{ml}$ of a $2 \cdot 5 \mu \mathrm{g} / \mathrm{ml}$ solution) was added and the culture was incubated at $37^{\circ} \mathrm{C}$ for one hour. After this time, the cells were spun down (as before), resuspended in prewarmed $0.075 M$ potassium chloride for $5 \mathrm{~min}$, spun down again, then gently fixed with 3:1 methanol:glacial acetic acid. The fixative was changed once. Slides were made by an air-drying technique and were banded using a standard trypsin G-banding method.

\section{Case 1}

\section{CLINICAL HISTORY}

The patient was a 70-year-old woman who, apart

Accepted for publication 29 June 1982 from surgical resection of a diverticular abscess of the sigmoid colon in 1960, had been well until August 1980. At this time, she developed parasthesiae of both legs, more severe on the left than the right, associated with numbness and weakness of the left leg. In April 1981, her right leg became weak and she had difficulty with micturition and constipation. Upon admission to the Radcliffe Infirmary, a lumbar puncture was performed and her CSF was found to contain 57 lymphocytes $/ \mu \mathrm{l}$, protein $1.9 \mathrm{~g} / \mathrm{l}$, and glucose $3.8 \mathrm{mmol} / \mathrm{l}$. No malignant cells were found, and the CSF pressure was normal. After three weeks in hospital, the patient regained considerable power in her legs with physiotherapy and was discharged without a diagnosis. The patient was re-admitted to hospital in July 1981 with a four-week history of leftsided pain which was particularly severe at night. Several days before admission the patient had become "shaky" whilst walking with a frame and had several episodes of incontinence with bifrontal nocturnal headaches. On examination, her legs were very painful to touch and her quadriceps were wasted. There was no lymphodenopathy or hepatosplenomegaly. Her CSF contained $363 \mathrm{WBC} / \mu \mathrm{l}$ (310 "polymorphs" and 52 lymphocytes, no red blood cells), and protein $2.8 \mathrm{~g} / \mathrm{l}$. Glucose was absent and organisms were not seen. The CSF lactate concentration was very high. Cytological study showed the majority of the cells to be lymphoplasmacytoid cells, many of which were in mitosis (Fig. 1). Bone marrow biopsy, blood count, ESR, and myelogram were normal. The patient was given prednisone and a five-day course of radiotherapy without improvement. By August 1981 the patient became drowsy and confused. Over the next week, her leg pain progressively worsened, she became unresponsive, and died in September 1981. 


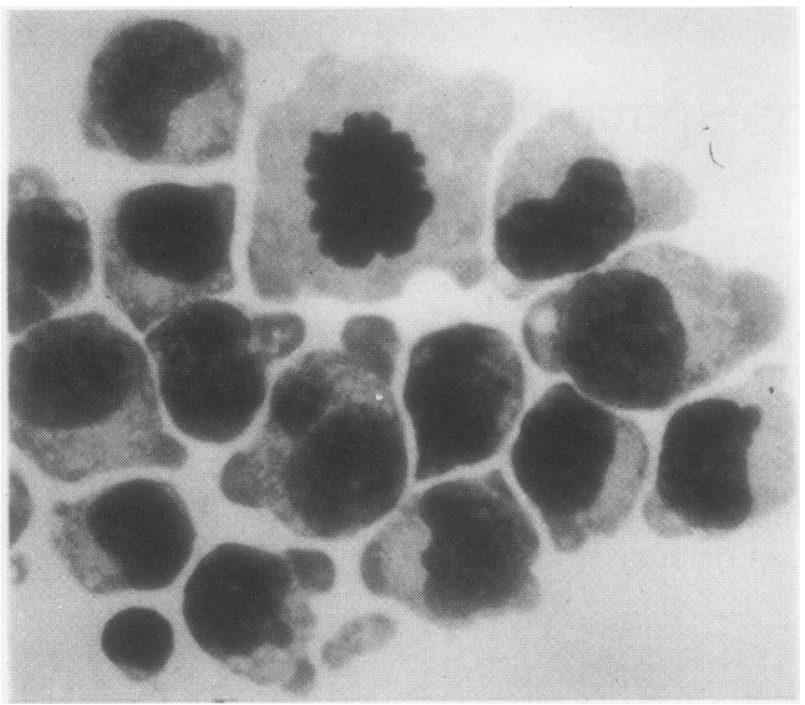

Fig. 1 Cytospin preparation from the CSF of case 1, showing lymphoplasmatoid cells, including one in metaphase. May-Grünwald-Giemsa $\times 1250$

\section{PATHOLOGY}

At post mortem, there was no hepatosplenomegaly or lymphadenopathy. A massive embolus was found within the right pulmonary artery with concomitant focal haemorrhagic infarction of the lung. Several haemorrhagic foci were also seen in the colon, and the kidneys displayed a moderate and somewhat patchy tubular necrosis. The brain weighed $1240 \mathrm{~g}$. It was diffusely swollen and the ventricles were symmetrically dilated. Microscopically, the ventricular surfaces, cerebral and cerebellar sulci, and the brain stem were covered by pleomorphic lymphocytoid tumour cells (Figs. 2 and 3). These tumour cell infiltrates were associated with small foci of necrosis, oedema, and demyelination. Gross tumour nodules were not found anywhere either within or outside the nervous system.

\section{CYTOGENETIC ANALYSIS}

This was performed during the patient's second hospital admission in July 1981. Twenty cells were examined from a direct preparation of the CSF. All cells showed an abnormal karyotype with chromosome numbers between 48 and 54 , and varying numbers of unidentifiable marker chromosomes. Certain markers were seen in all the cells examined. Six cells were fully analysed as shown below:

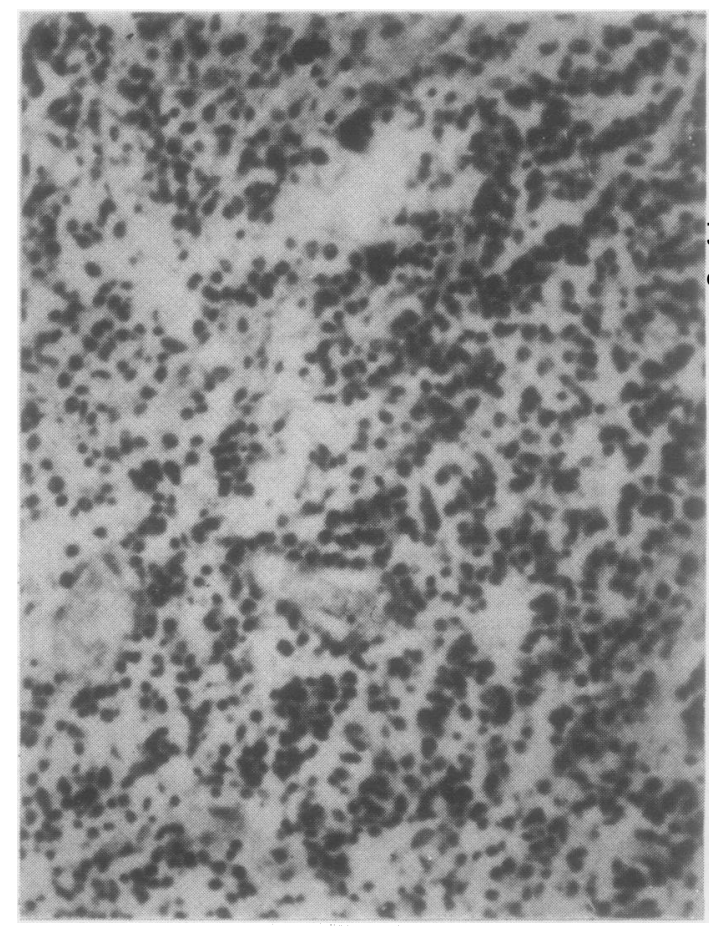

Fig. 2 Case 1, necropsy material. Subarachnoid infiltrate of mononuclear cells. Haematoxylin and eosin $\times 400$

\begin{tabular}{llll}
\hline Cell no & No of chromosomes & Analysis & \\
\hline 1 & 51 & $-4-4-6-8-9-10-14+\mathrm{X}+\mathrm{X}+12$ & +9 markers \\
2 & 51 & $-4-4-6-8-9-10-15+\mathrm{X}+\mathrm{X}+12$ & +10 markers \\
3 & 49 & $-2-6-8-8-9-13-15-15-16-19+\mathrm{X}+\mathrm{X}+12$ & +10 markers \\
4 & 51 & $-2-6-6-8-11-15+\mathrm{X}$ & +7 markers \\
5 & 48 & $-4-6-7-8-8-9-10-13-16+\mathrm{X}+\mathrm{X}+\mathrm{X}+\mathrm{X}$ & +8 markers
\end{tabular}

Cell No 1 is illustrated in Fig. 4. 


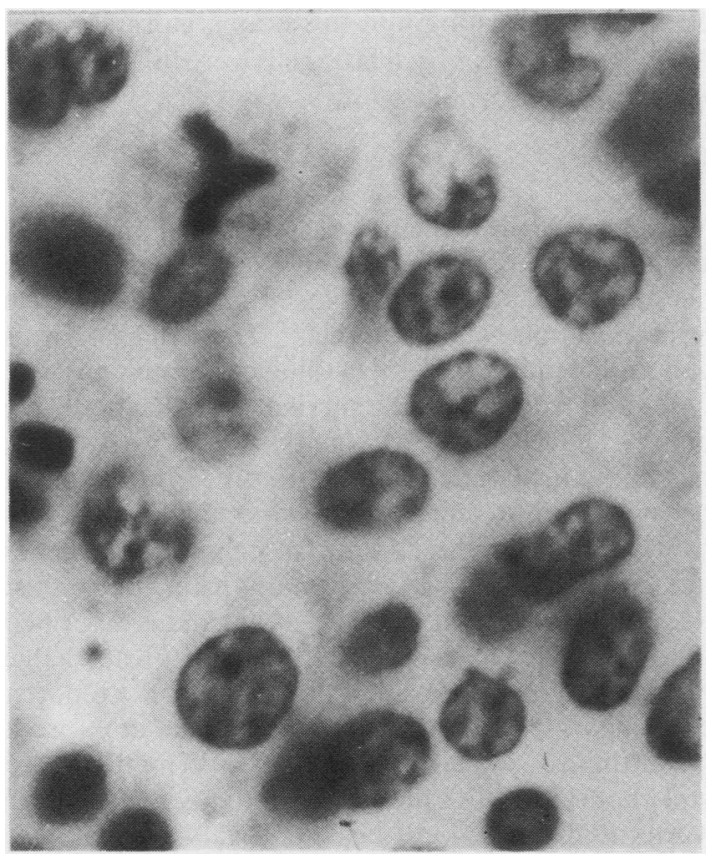

Fig. 3 Case 1. Detail of the infiltrate of

lymphoplasmacytoid cells found at necropsy. Note the tripolar mitotic figure. Haematoxylin and eosin $\times 1440$
The remaining cells could not be fully analysed but all showed abnormalities similar to the above cells. One of the marker chromosomes which was present in all the cells could be identified as a No 3 with extra material on the short arm $(3 p+)$. The similarities between these different cells could hardly have occurred by chance, and it can only be concluded that all the available dividing cells belong to a neoplastic clone.

\section{Case 2}

\section{CLINICAL HISTORY}

A man aged 58 yr presented with pain in the left hip and leg. Six years previously he had been treated with combined chemotherapy for a diffuse non-Hodgkin's lymphoma, diagnosed by biopsy of a left axillary lymph-node. On review, this was a high grade lymphoma, either centroblastic or immunoblastic. He responded well to this, and was well for $5 \frac{1 / 2}{\text { yr }}$ except for an episode of heart-block for which he needed a pacemaker. Six months before the present episode he had been treated by radiotherapy for superior vena cava obstruction and a left pleural effusion, which contained abundant lymphoma cells.

On admission he was found to be anaemic and jaundiced, and he had para-aortic lymphadenopathy. The pain in his left leg was associated with weakness and some loss of sensation, and a myelogram revealed a cauda equina lesion attributable to lymphomatous infiltration. Lumbar puncture at this time produced a fluid with a protein of $3.5 \mathrm{~g} / \mathrm{l}$, a much reduced glucose, and 316 cells $/ \mu \mathrm{l}$, almost all of them lymphoma cells of the same type seen previously in the pleural fluid (Fig. 5).

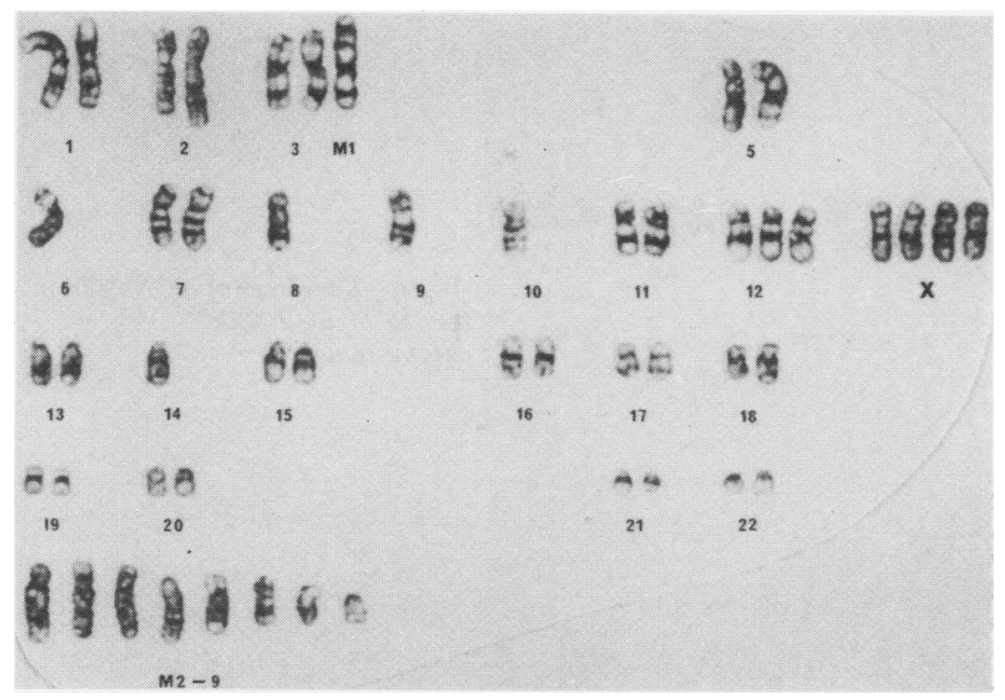

Fig. 4 Karyotype of cell no 1 from the CSF of case 1, with 51 chromosomes. 


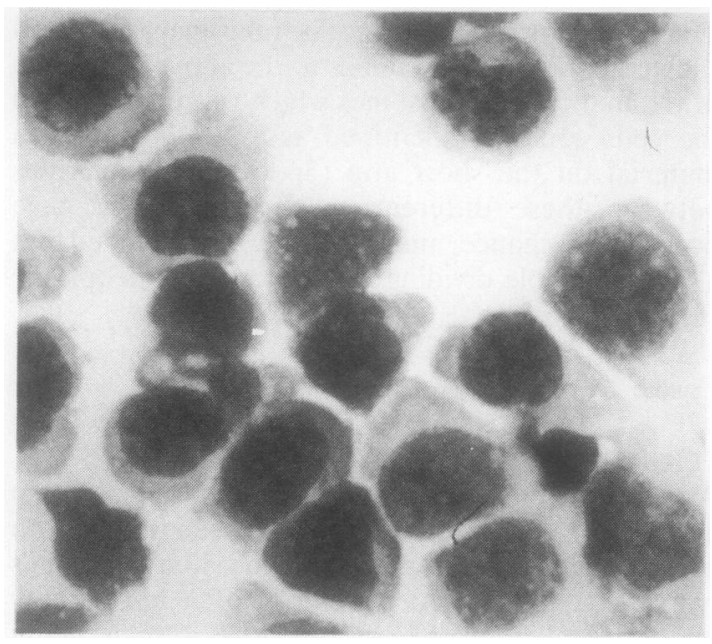

Fig. 5 Cytospin preparation from the CSF of case 2, showing exclusively lymphoma cells. May-GrünwaldGiemsa $\times 1250$

\section{CYTOGENETIC ANALYSIS}

Ten cells were examined from a 24-h culture of the CSF. All cells showed an abnormal karyotype with chromosome numbers between 62 and 75 and varying numbers of unidentifiable marker chromosomes. Certain markers were present in all the cells examined, indicating that this is an abnormal clone. Modal number was 73 . Three cells were fully analysed as shown in the Table below.

\section{Discussion}

Meningeal lymphoma may occur as a complication of systemic lymphoma (excluding ALL), and may also be seen as a primary manifestation, particularly in immunosuppressed patients. The diagnosis is generally established by cytological examination of CSF, and with increasing survival such diagnoses are being made more frequently. ${ }^{1-3}$ However, the morphological diagnosis is more difficult than might be supposed. Numerous transformed lymphocytes showing mitotic activity may be seen in CSF samples in benign conditions, particularly viral meningitis; this has been known for many years and is described in the standard texts on CSF cytology. ${ }^{4-9}$ Knowledge of this should prevent "false-positive" reports, especially if Romanowsky methods are used. Nevertheless, mistaken diagnoses of lymphoma are still reported in the literature, and a recent article ${ }^{10}$ warns that one should be "very wary of making a diagnosis of . . . lymphoma on a patient with no clinical history of systemic malignancy unless the morphology is extremely compelling."

Since a false-positive report has such serious

\begin{tabular}{lll}
\hline Cell no & No of chromosomes & Analysis \\
\hline 1 & 73 & $-5-14-17-19-\mathrm{X}-\mathrm{Y}+12+15+18$ \\
2 & 75 & $-5-10-14-14-19-\mathrm{X}-\mathrm{Y}+8+9+12+15+18+20$ \\
3 & 72 & $-6-7-10-13-14-14-17-19-19-20-\mathrm{X}-\mathrm{Y}+2+4+18$ \\
The remaining cells were counted as follows: & 62 & 667070737375
\end{tabular}

Cell No 2 is shown in Fig. 6.

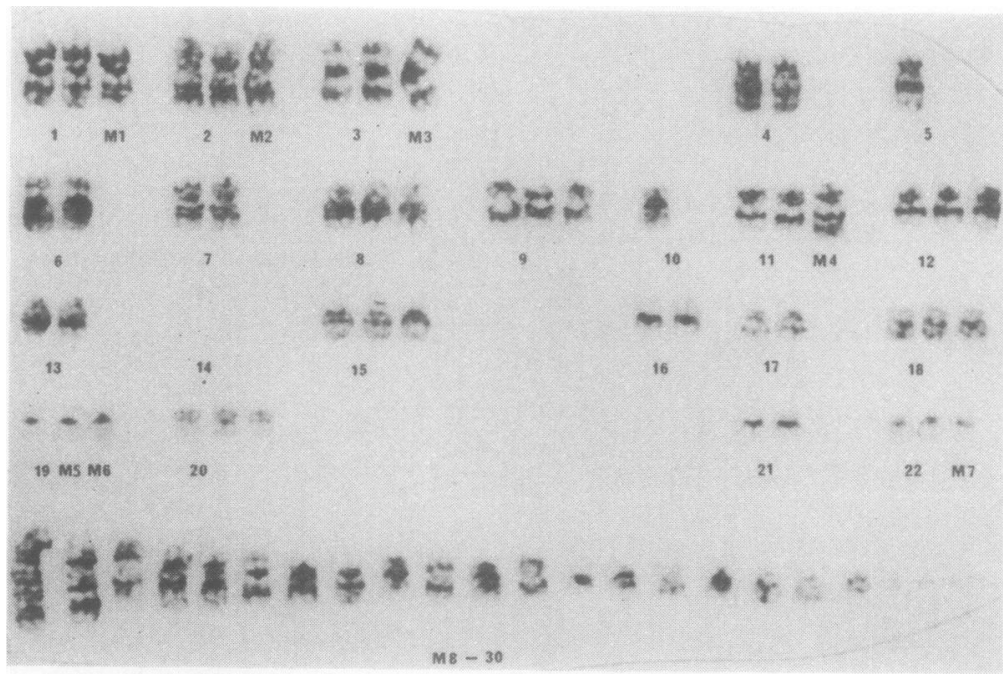

Fig. 6 Karyotype of cell No 2 from the CSF of case 2, with 75 chromosomes 
consequences, objective methods should be used to confirm the diagnosis whenever possible. One method is to demonstrate monoclonality with the aid of surface markers. ${ }^{11}{ }^{12}$ Similarly, the demonstration that the dividing cells within the sample have an abnormal karyotype provides convincing evidence. Such cells may vary to some extent but have features common to the particular clone such as specific marker chromosomes. Lymphoma cells usually show distinct variations from the normal chromosome set, ${ }^{13}$ and in this context an aneuploid or pseudodiploid clone can confidently be regarded as neoplastic.

In case 2 , the patient was known to have a malignant lymphoma, and cells similar to those found in the CSF were also noted in the pleural fluid; consequently, cytogenetic study only furnished additional confirmation. However, in case 1 , the cytogenetic findings were crucial in proving that the lymphoid cells found in CSF were in fact neoplastic.

For this technique to succeed one needs sufficient cells either in division or about to divide. The paucity of cells in most CSF specimens is presumably the reason why this test has not, to our knowledge, been previously applied in cases of suspected lymphoma. Apart from leukaemia ${ }^{14}$ we are aware of five reports of cytogenetic analysis of cells in CSF with a view to the diagnosis of neoplasm. Baughman and Hirsch ${ }^{15}$ cultured cells obtained post mortem from CSF in a case of malignant glioma, as well as from other conditions, but clearly abnormal karotypes were not obtained. In the subsequent four reports the diagnoses were medulloblastoma, ${ }^{16}$ retinoblastoma, ${ }^{17}$ adenocarcinoma of bronchus ${ }^{18}$ and malignant melanoma, ${ }^{19}$ and all these showed chromosomal abnormalities.

This is a very small number considering that the necessary technology has existed for over $20 \mathrm{yr}$. Perhaps the realisation that it is possible may stimulate others to use this valuable confirmatory test in appropriate cases.

We are grateful to Prof WB Matthews and Dr RA Griffiths for permission to report case 1, and to Dr JM Holt for permission to report case 2 .

\section{References}

' Rawlinson DG, Billingham ME, Berry PF, Kempson RL. Cytology of the cerebrospinal fluid in patients with Hodgkin's disease or malignant lymphoma. Acta Neuropathol 1975;suppl 6:187-91.

${ }^{2}$ Herman TS, Hammond N, Jones SE, Butler JIJ, Byrne GE, McKelvey EM. Involvement of the central nervous system by non-Hodgkin's lymphoma. Cancer 1979;43:390-7.

${ }^{3}$ Levitt LJ, Dawson DM, Rosenthal DS, Moloney WC. CNS involvement in the non-Hodgkin's lymphomas. Cancer 1980;45:545-52.

${ }^{4}$ Sayk J. Cytologie der Cerebrospinalflüssigkeit. Jena: Fischer, 1960.

${ }^{5}$ Greger J, Wieczorek V. Über das Vorkommen von Plasmazellen im Liquor cerebrospinalis bei neurologischen Erkrankungen. Wien Z Nervenheilk 1966;23:366-74.

- Spriggs AI, Boddington MM. The cytology of effusions and of cerebrospinal fluid. 2nd ed. London: Heinemann, 1968.

7 Dufresne J-J. Praktische Zytologie des Liquors (Documenta Geigy). Basel: Ciba-Geigy, 1973.

${ }^{8}$ Oehmichen M. Cerebrospinal fluid cytology. Philadelphia: Saunders, 1976.

${ }^{9}$ Kölmel HW. Atlas of cerebrospinal fluid cells. Berlin: Springer, 1976.

${ }^{10}$ Borowitz M, Bigner SH, Johnston WW. Diagnostic problems in the cytologic evaluation of cerebrospinal fluid for lymphoma and leukemia. Acta Cytol 1981;25:665-74.

" Oehmichen M, Huber H. Supplementary cytodiagnostic analyses of mononuclear cells of the cerebrospinal fluid using cytological markers. J Neurol 1978;218:187-96.

${ }^{12}$ Goodson JD, Strauss GM. Diagnosis of lymphomatous leptomeningitis by cerebrospinal fluid lymphocyte cell surface markers. Am J Med 1979;66:1057-9.

${ }^{13}$ Rowley JD, Fukuhara S. Chromosome studies in non-Hodkin's lymphomas. Semin Oncol 1980;7:255-66.

${ }^{14}$ Mastrangelo R. Zuelzer WW, Ecklund PS, Thompson RI. Chromosomes in the spinal fluid: evidence for metastatic origin of meningeal leukaemia. Blood 1970;35:227-35.

is Baughman FA, Hirsch B. Karyotyping of cells from cerebrospinal fluid. Lancet 1963;ii:417.

${ }^{16}$ Spriggs AI, Boddington MM. Karyotyping of cells from cerebrospinal fluid. Lancet 1963;ii:636.

${ }^{17}$ Inoue S, Ravindranath Y, Ottenbreit MJ et al. Chromosomal analysis of metastatic retinoblastoma cells. Humangenetik 1974;25:111-8.

${ }^{18}$ Granberg-Öhman IF, Anderson BI, Gupta SK, Lying-Tunell UM. Chromosome analysis in meningeal carcinomatosis. Acta Neurol Scand 1979;60:255-9.

${ }^{19}$ Kristoffersson U, Dahlquist E, Mitelman F. Cytogenetic diagnosis of meningeal carcinomatosis. N Engl J Med 1980;303:1479.

Requests for reprints to: Dr AI Spriggs, Laboratory of Clinical Cytology, Churchill Hospital, Headington, Oxford OX3 7LJ, England. 